\title{
CONTESTING THE MEANINGS OF DISASTER: AN ANTHROPOLOGICAL STUDY ON YOGYAKARTA PEOPLE'S RESPONSES TO THE MAY 27, 2006 EARTHQUAKE
}

\author{
Mohammad Hasan Basri \\ Arouna Institute, Jakarta
}

\begin{abstract}
ABS̈TRAC̈̈
Geograficly, Indonesia is a country with potentials of and even vulnerable to disaster, both natural and man-made disaster. Nevertheles, researchers and academicians, especially local scholars, have paid little attention to seriously get involved in to dissaster studies, especially from the point of view of social science. Thus, this paper is an effort to start working on dissaster studies in the country and is intended to encourage the growing of dissaster studies within the context of social sciences. It concludes that the process of contestation of meaning in responding the eartquaqe dissaster by people of Yogyakarta is influenced by three significant elements including religious meaning, Javanese meaning and scientific meaning. Although the three are interelated, based on Wonokromo peple's responses to Yogya eartquaqe, religious meaning has dominated the mind of people in Wonokromo. In addition, there are four varians of meaning that is based on religion including dissaster as punishment, as cchallage, as test and as love from God. These responses implisitly show the problematics of thought of the people, especially with regards to theodicy (the problem of evil) in terms of theology and dissaster recovery process due to the tendency of blaming the victims.
\end{abstract}

Kata Kunci: kajian bencana, gempa, agama, Jawa, dan sains.

\section{INTRODUCTION}

Our present life and also of course, the future, is in a challenging time indeed. We are in the threat of natural disasters and man-made disasters. We can see the indication such as global warming, extreme climate change, and environmental crisis hitherto. According to Dore, ${ }^{1}$ all kinds of disaster have extremely increased in the current decade. Those disasters comprise

1 Mohammed H.I. Dore and David Etkin, "Natural Disasters, Adaptive Capacity and Development in the Twenty-first Century" in Mark Pelling, Natural Disasters and Development in A Globalizing World, p.77-79. 
hydro-meteorological disasters like droughts, extreme events, floods, and windstorms; geophysical disasters including earthquakes, slides, volcanic eruptions and wave/surges; and other disasters including epidemics, famines, insect infestations, wildfires, etc.

The recent disaster that has been fresh in the mind of Indonesian people is the Yogyakarta earthquake. It occurred on Saturday morning at 5:54 a.m., $27^{\text {th }}$ May 2006. The influences of the 5.9 quake on the Richter scale were more than 6,000 people died, more than 50,000 people injured, and around 70,000 buildings were damaged. It was historically the worst earthquake that has ever shaken Yogyakarta. ${ }^{2}$

The occurrence was so terrible, since it caused not only a great loss of life and buildings but also psychologically, it left trauma over the hearts of the victims. Besides, on a cognitive level, the earthquake's occurrence challenged people's worldview with profound existential questions that produce various responses.

Interestingly, based on my observation as a volunteer in a recovery and relief project, I found various responses that emerged during and the aftermath of the earthquake. One of the common responses is bringing up the name of God or in other words, they responded with religious terms to get the meaning and explanation. Regarding this tendency, Hoffman and Oliver-Smith also affirmed that to search for meaning and explanation of the disaster, people in some extents, come to the fore in matters of religion.

Individuals and societies face numerous cosmological dilemmas and concrete problems that provoke distress and require solution. People search for meaning and explanation, bringing to the fore matters of religion and mortality. They launch observances and rituals. They devise ways to express grief and mourning. ${ }^{3}$

Nevertheless, in the Javanese societal context, I was convinced that religious meaning is not the only way people responded. When the earthquake happened there were other explanations such as myth, in which people attempted to relate it with the occurrence of the earthquake and scientific explanations published in newspapers or broadcasted on television.

2 Before 2006, the earthquake have shook Yogyakarta in 1867 (5 people died and 372 buildings destroyed), in 1943 (213 people died, 2.096 people injured, and 2.800 buildings damaged), and in 1981 (no people died only Ambarukmo Hotel's wall cracked), see the special reportage on $27^{\text {th }}$ May 2006 earthquake in TEMPO, June 11, 2006.

3 Susanna M. Hoffman and Anthony Oliver-Smith, "Anthropology and the Angry Earth: an Overview" in Anthony Oliver-Smith and Susanna M. Hoffman, The Angry Earth: Disaster in Anthropological Perspective, p. 8. 
According to Fahmi Amhar, when a disaster happens people tend to find explanation whether from myth, science, or faith (religion):

At the last time, when a big storm attacked Yogya, people made 17 colors of porridge as offerings to the spirit. This kind of ritual is of course not scientific, but as the matter of fact, it has been carried out for centuries. When scientific explanation cannot much help in understanding an occurrence of natural phenomena such as disaster, people usually return to the myth or mystical practices. Not only in Yogya, in the advance countries like Japan and USA, myth still exists. This matter is actually related with the need of people to the spirituality as human being's primordial substance. ${ }^{4}$

This point inspired me to inquire further the other aspect beyond religious meaning. I then decided to scrutinize the inquiry by doing field research in Wonokromo village, ten kilometers to the south from Yogyakarta city. Conducting research in this village is interesting for several reasons. Wonokromo is wellknown as a"santri village", there are many pesantren there (11 pesantren) in which many students who have been studying in some universities in Yogyakarta city live in the pesantren. In the village, I also attended the annual ritual "Rebo Bungkasan" to commemorate the first religious figure who initially had brought Islam in the village. In addition, when the earthquake happened on May 27, 2006, Wonokromo was one of the villages with serious damages and losses (91\% totally destroyed).

Based on the aforementioned impression, I hypothesize religion, myth and science will be a basis of understanding in the way people respond to the occurrence of the earthquake.

Additionally, to study a disaster such as an earthquake is as natural laboratory to learn many aspects of society and culture, as Susanna M. Hoffman's suggestion:

It has been suggested that disasters function as the closest thing a student of society ever approaches to a natural laboratory. Calamities take a people back to core, and in the rubble remaining, a researcher can behold the fundamental constructs that underpin the social world and, thread by thread, observe the web of the world and worldview as they are spun again. Many aspects of a society and culture are unclothed in the aftermath of a disaster. ${ }^{5}$

4 Fahmi Amhar, "Mitos, Sians dan Iman in the Midst of Disaster" in Kedaulatan Rakyat, June 12, 2006.

5 Susanna M. Hoffman is an independent researcher in anthropology. She wrote some books on disaster study on anthropological perspective. See further one of her writings, "After Atlas Shrugs: Cultural Change or Persistence after a Disaster" in Anthony Oliver-Smith and Susanna M. Hoffman (Eds), The Angry Earth: Disaster in Anthropological Perspective, p. 310. 
In sum, at a time of scarce of disaster study in this country, I expect this work will give a significant contribution academically and open the broader discussion of disaster studies particularly in terms of social and cultural sciences.

\section{THE CONSTRUCTION OF MEANINGS}

By recognizing the chronicle occurrence and the villagers' responses to the earthquake, it is obvious that the occurrence of the earthquake was not a mere tragedy that is full of personal sufferings and losses, a disaster also affects social function of society. In this point, Charles E. Fritz explains the impacts of disaster in socio-cultural context:

A disaster is an event that disturbs the vital functioning of society. It affects the system of biological survival (subsistence, shelter, health, reproduction), the system of order (division of labor, authority patterns, cultural norms, social roles), the system of meaning (values, shared definitions of reality, communication mechanisms), and the motivation of the actors within all of these systems. ${ }^{6}$

From Fritz's categorization on the affects of a disaster to social function above, one point that I want to emphasize in the next discussion is the effect on the system of meaning. This means that the earthquake occurrence on the $27^{\text {th }}$ May 2006 will be the main focus in which I attempt to scrutinize how far the occurrence affected Wonokromo villagers' system of meaning. In doing so, Meredith B. McGuire's concept on meaning system construction is helpful. According to her, an individual's meaning system is not constructed from nothing, since each individual has a set of meanings that is greatly influenced by family, friends, institutions (e.g. education), and the larger society. The main means of the meaning construction is socialization where an individual comes to accept, reject or modify meanings. In other words, an individual will choose which meaning among several competing meanings. ${ }^{7}$

Hence, in the following discussion, I would like to look at the villagers' responses by tracing their meaning system construction, what factors influence them and how those meanings are contested. There are three kinds of meanings constructed in which I can categorize from the villagers' responses.

The first category is religious meaning. To categorize responses into religious meaning, I primarily look at some terms and themes in which they employ

6 Charles E. Fritz affirmed that these two perspectives must be kept in mind in any balanced treatment of the social aspects of disaster. See, his writing "Disasters" in David L. Sills (Ed) International Ecyclopedia of Social Sciences, Vol. 4, p.202.

7 Meredith B. McGuire, Religion: The Social Context, p.24-25 
religious reflection and articulation regarding the occurrence of the earthquake. The first thing that I categorize as religious meaning is the reflexive utterance referring to the transcendent/supernatural. They stood on their personal meaning system in believing that whatever and whenever happen in this world is God's will. Karen Armstrong said that during a period of extremity, people indeed need an infusion of divine energy. ${ }^{8}$ Thus, that's why the first expression then is returning to God.

In this condition, an individual is questioning the existential matter as being in a very crucial state. According to Meredith B. McGuire, the extra ordinary event such as earthquake is a time of meaning-threatening ${ }^{9}$, which touches an individual's existing personal meaning system. One will try to reflect the event with the very fundamental and existential question; what kind of understanding and perspective that could affirm or contradict with the existing meaning system. As regards this point, Anthony Oliver-Smith pointed out that the extreme conditions created by disaster occurrence frequently challenge people's worldviews with profound existential question for which meanings consistent with circumstances must be elaborated. ${ }^{10}$

Since the existing personal meaning in the minds of the villagers is shaped by religious understanding, they tended to respond to the extreme events religiously. It can be seen in the ways in which the villagers correlated the earthquake with the transcendent power since they have no explanation except from a religious perspective i.e. returning to the Omnipotent Being as the Creator of the earth.

At this point, by infusing the divine energy in the meaning system, an individual will escape from, in terms of logotherapy, the existential vacuum ${ }^{11}$. One attempts to search within him/herself for a meaning that compromises or adjusts with the existing meaning system.

In the case of Nurhidayati ${ }^{12}$, she felt that there was a spirit or divine energy that tried to inform something. In the psychology of religion, this kind of feeling

8 Karen Armstrong, A Short History of Myth, p.70.

9 McGuire, Religion: The Social Context, op. cit. p.26.

10 Anthony Oliver-Smith, "Theorizing Disasters: Nature, Power, and Culture" in Catastrophe \& culture: The Anthropology of Disaster, p. 38.

11 Existential vacuum is a stance when one has no meaning or in the state of meaningless. This concept was introduced by Viktor E. Frankl in his well-known theory "logotherapy". See further his concepts in Man's Search for Meaning. In Indonesia, this concept has been developed by Hanna Djumhanna Bastaman, see his initial analysis on logotherapy, Dimensi "Spiritual" dalam Teori Psikologi Kontemporer: Logoterapi Viktor E. Frankl, in Ulumul Qur'an No.4,Vol.V,1994,

12 Nurhidayati is 42 years old teacher; she has been teaching physic in Junior High School. Besides, she is also a local religious leader of Islamic organization (Muhammadiyah) in the district stage. The interview was held on April, 18 and 23, 2007. 
is taken as experiential dimensions that belong to an individual to indicate the presence or absence of a divine spirit. ${ }^{13}$ When they got an adjustment, they would feel the presence of God that made them more released from their meaningless state. They would be more accepting to whatever they are.

While in the case of Imaduddin ${ }^{14}$, the pattern of his adjustment is related to his position in the community, as a religious figure who leads the prayer in funeral processions. When he got a feeling to memorize the words of prayer, he also felt the presence of divine energy that was adjusted with its function to later use what he has memorized. So, he got functional legitimization from his memorization not only as an individual to release his existential vacuum but also as religious leader.

I come to the second thing that I categorize as religious meaning. The categorization I made by looking at the religious terms in which the villagers named or gave meaning to the earthquake. There are four categories expressed by the villagers. The first category is that the earthquake was a punishment from God. Like indicated in the case of Imaduddin, this term is used by the villagers to recognize that the miscreants and the sinners were the cause of the earthquake. The second category is a warning. God warns human beings through the occurrence of the earthquake, to remind and repent to God's teachings. Based on the villagers' responses, a warning from God is the most common and frequent religious response recognized by them. For instance, Katib's ${ }^{15}$ expression, the warning was addressed to Muslims, since for him God wants to warn his believers strengthen their faith. While in the mind of Daman ${ }^{16}$, God warned the corruptors to change their wrong deeds and

13 See further, Raymond F. Paloutzian, Invitation to the Psychology of Religion, p.1718.

14 Imaduduin is a 63-years Kiai (religious title for Islamic leader) who is teaching and guiding around 50 children to learn the Qur'an. He continued his father's dedication to develop pesantren al-Baiquniyyah, it is located in the western part of Wonokromo village. The interview was conducted on March, 12 and 14, 2006.

$15 \mathrm{Katib}$ is also a Kiai who leads pesantren Fadlumminallah. He is 48 years old. There are around 100s students who study there. When I met him, he was repairing his motorbike in front of his unfinished house; the household goods and equipment look a mess. I was asked to come into the guest room, eventhough the room has been renovated, also the situation became so familiar since he welcomed me with warm acceptance by serving a cup of tea and crackers. The interview conducted on March 12 and July 8, 2007.

16 Daman is an old farmer; 71 years old. When I met him, he was just getting rest after cutting grass for his goats on the bund of his rice field. On May 2, 2007, I was interviewing him while he was enjoying his cigarette by rolling little tobacco and a piece of paper. And on July 8,2007 , I met him again in his house. On this second meeting, he also showed and told me that Javanese people used to natural sign such the above story and they also usually read primbon (Javanese prediction book) to see the meanings behind a certain occurrence, in that book stated what would happen in the society when the earthquake occurred. Hence, he argued that today, Javanese people seldom to use it again, probably only the old people 
to remember the Omnipotent. And in Nurhidayati's reflection, the warning from God was more personal in the sense of strengthening worship with God. The third category is a test, whether human beings can pass the examination given by God or not. In Husnan's ${ }^{17}$ understanding, if human beings are able to accept the test, s/he will get guidance from God.

Those categories are religious terms in which, historically, have been disputed over generations for centuries to reconcile God's mercies on one hand, but on the other hand there are many sufferings and evils in this world or this matter is called theodicy. One of the explanations that can be given for these four expressions- and that may explain the dominance of religious meaningis theological. It has been a subject of controversy since the early period of Islam. And one strain of it was carried down through generations, reaching the majority of Muslim consciousness today.

The second category is Javanese meaning. The term "Javanese meaning" here refers to the local recognition and beliefs regarding the occurrence of the earthquake. It refers to the narratives that emerged during the earthquake i.e. Javanese mythology that has been orally generated in the mind of Javanese people, for instance, like the three versions of the mythology of Nyai Roro Kidul and the mythology of Kyai Antoboga as described in the previous chapter. Thus, the Javanese meaning here is only simplified in the mythology raised when the earthquake occurred.

In this part, it is important to discuss what relationship and function of those mythologies in the minds of Javanese people. To see and to analyze the Javanese mythology and the earthquake in Yogyakrata, Heddy Shri AhimsaPutra's view is helpful to see the relational pattern of the elements within the mythology. ${ }^{18}$

One of the relational patterns to understand the Javanese mythology is prophetic relation. According to Ahimsa-Putra, prophecy is the significant element in the life of Javanese people. A certain prophecy becomes a means of legitimization by the authority or an explanation on the occurrence in a certain time. Yet, a prophecy is also multi-interpretable. Thus, it will be tried to be matched and justified with a certain occurrence. In Javanese life, there

17 Husnan is a 76 years-old Islamic leader; he manages Islamic kindergarten school and Islamic elementary school. On March 14, 2007, when I was interviewing him, he was looking after his granddaughter in the veranda of his simple house since the house has been renovated.

18 By analyzing the mythology in the text of Babad Tanah Jawi and the process of syncretism in Javanese culture, Heddy Shri Ahimsa-Putra categorized some relational patterns in analyzing Javanese mythology i.e. genealogical, analogical, empiric, prophecic, and cooperative relations. See further, Strukturalisme Lévi-Strauss: Mitos dan Karya Sastra, p.349-386. 
is a well-known term "othak athik", "gathuk", and "nggathuk-nggathukke". The terms mean assuming things that seemingly have no relationship to one another, as if they are really interrelated and understandable. ${ }^{19}$

This prophetic relation can be seen in the three versions of the myth narrated by the villagers. In the first and the second version, the relational pattern can be explained that Javanese people try to relate and justify the occurrence of the earthquake with two powers in Javanese mythology i.e. Nyai Roro Kidul as the queen of southern ocean and Eyang Sapujagat as the king of mount Merapi. In the first version, the occurrence of the earthquake was related to the jealousy and the anger of Nyai Roro Kidul since the people of Yogyakarta paid more attention to mount Merapi (people were aware of the activity of the mount) rather than the southern ocean. While in the second version, the relational pattern is seemingly more reciprocal in the sense that Nyai Roro Kidul welcomed and agreed to marry her daughter off Eyang Sapujagat.

In the last version, the relational pattern is linked with the process of the river Opak formation and the sound coming from beneath the river. By recognizing the mythology it can be fathomed that in the past, the people used to believe the occurrence of the earthquake was influenced by the eruption of mount Merapi (volcanic earthquake). This prophetic relation can also be traced in ancient texts as explained by Daman when he told about the gold chart before the earthquake happened that Javanese people used to understand a certain occurrence by connecting it with natural phenomena as stated in the primbon.

The third category is scientific meaning. By scientific meaning, I mean it as natural explanation to natural events. The villagers' responses showed that they have a little scientific understanding of the earthquake that happened on $27^{\text {th }}$ May 2006. However, I think they actually have such understanding, but ultimately it was subsumed under their religious understanding.

In the case of Katib, he was convinced that scientific inquiry was more sensible rather than the myth that Nyai Roro Kidul was angry. He perceived that the occurrence of the earthquake was part of the cause-effect law (sunnatullah). Yet, he stated that the cause of the earthquake was the people were careless of God's commandment. They knew the explanation of the earthquake from scientists through newspaper and electronic media such as television and radio. We can also see in the case of Yunus ${ }^{20}$ Nurhidayati, to understand a natural phenomenon such as an earthquake, Yunus needed more acceptable and more rational evidence i.e. by scientific explanation. While Nurhidayati,

19 Ibid, p.373.

20 Yunus is a youth (25 years old) who involved in Sub-district (Kecamatan) Development Program (PPK), I interviewed him twice; on $16^{\text {th }}$ May 2007 and on $5^{\text {th }}$ July 2007. 
as a teacher, he wanted to broaden her knowledge about natural changes. However, at the same time, Yunus stands on his religious belief of God's predestination, while Nurhidayati perceived that to broaden her knowledge is to realize a sign of God's omnipotence behind the natural phenomena.

The next discussion that I want to emphasize is to relate the condition of people having little knowledge or understanding on the earthquake (natural explanation) with the concept of vulnerability. In terms of disaster studies, people's vulnerability is an urgent and interesting discussion, since to talk about the concept of vulnerability is not simply understanding societies in the risk condition, yet it is a also about their perception and knowledge. ${ }^{21}$ There are two ways to understand the vulnerability of people to an earthquake in a particular area; ex ante (potential) and ex post (what happens after the initial shock and the process of recovery). ${ }^{22}$ Thus, in this way, I attempt to see the villagers' experience in the early moments when the earth shook Yogyakarta, when the issue of a tsunami spread out, how the people dealt with the disaster, and how the process of recovery ran as a means to look at how vulnerable the people were at that time.

First, to exemplify the ways of vulnerability (ex ante and ex post), we can see the case of Daman and Nurhidayati. When the rumor of a tsunami spread out, Daman climbed a coconut tree and Nurhidayati brought his family to the hill. How panic and chaotic the situation was at that morning, there were a large number of people that strived to save their life by going to the northern area as the higher region in Yogyakarta or by reaching to the higher place. On the other hand, there were a number of people who were convinced at that time that it was impossible for a tsunami to reach Yogyakarta. So, they persuaded the people to stay and go nowhere, like what was done by Akhid ${ }^{23}$ (he knew and he was very sure that the tsunami would not happen) and Imaduddin in convincing the people and get rid the chaotic situation.

From this example, the way of vulnerability emerged related with the potential (ex ante) of the people to face and deal with the earthquake and the rumor of a tsunami. When the people lacked understanding and knowledge, they tended to be vulnerable in the sense that they had no knowledge about what

21 Vulnerability is a broad concept that needs multidisciplinary approaches. Thus, what I discuss here is only related with vulnerable people regarding to their understanding, perception, and knowledge on earthquake. To know the conceptualization of vulnerability in the more comprehensive and more holistic way, see Greg Bankoff, Georg Frerks, and Dorothea Hilhorst (Eds), Mapping Vulnerability.

22 see, Ben Wisner, Piers Blaikie, Terry Cannon, and Ian Davis (Eds), At Risk: Natural Hazards, People's Vulnerability and Disasters, p.276.

23 Akhid is a teacher in Islamic Senior High School. He is 44 years old. He teaches geography on the third year class. The interview was carried out on April 17, 2007. 
they should do in the chaotic situation. Moreover, in this point, the situation was worsened by the disability of the authority (such as governmental agency and public media) to give sufficient procedure of mitigation and of recovery (ex post). Inversely, although only a few number of individuals who had knowledge and cognitive consciousness in overcoming the chaotic situation, the vulnerability could fade away a little bit. Thus, the vulnerability depends on the access of resources and the capability of applying knowledge. ${ }^{24}$ The more people can access and apply their knowledge, the more people's vulnerability can be reduced.

\section{THE CONTESTATION OF MEANINGS}

After exploring and categorizing the meanings recognized by the villagers, it is time to discuss the contestation of those meanings in the cognitive level of the villagers. To show the pattern of contestation among those above three meanings, the scheme below is probably sufficient. Through the scheme above, it can be described that there are three streams of meanings that influence and shape the process of meaning construction in the minds of the villagers. Every meaning necessarily affects each other in a cognitive way. Thus, in the case of the $27^{\text {th }}$ May 2006 earthquake, the process of meaning construction in the personal meaning system belonging to every villager will be respectively diverse from one to another. I see the intertwined relationship among them; one stream seems to defeat another stream, and so forth. It depends on how far those three streams (religion, Javanese belief, and science) cognitively affect him/her to respond to the occurrence.

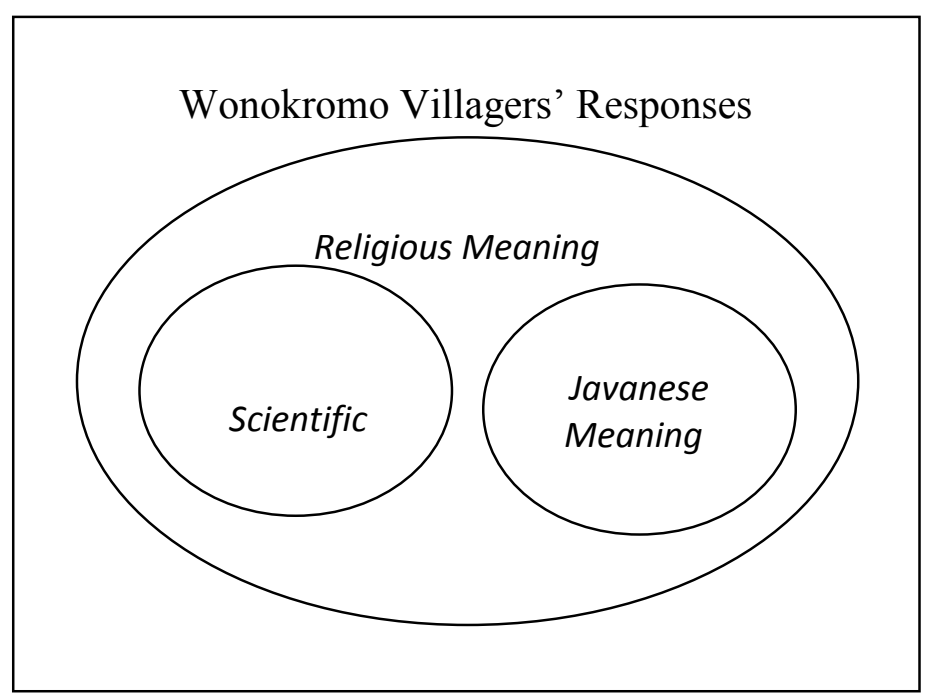

24 Ibid, p.277. 
Nevertheless, from the scheme, the villagers' meaning construction can be simply described as religious meaning being the strongest influence in the way they perceive the occurrence of the earthquake. While Javanese meaning and scientific meaning, although both of them also affect the villagers' mind, they are under the influence of religious meaning. To clarify the religious meaning domination within the process of the contestation, I attempt to analyze the contestation between religious meaning with Javanese meaning and between religious meaning and scientific meaning.

\section{Religious Meaning Vs Javanese Meaning}

Syirk, is the very idea of thought considered by Muslims in some extents in understanding Javanese notions. They think that believing in a certain notion especially in spirits will deprave the faith. In the earthquake matter, this perception was also raised and contested in the mind of the villagers.

We can see it in the case of Mujtamar that he was very worried of committing syirk if he believed in the existence of Nyai Roro Kidul or in Nurhidayati's recognition that she was very committed to obliterate what she called "syirk", like believing in spirit or rituals.

I think, the root of the contestation originates in the idea of purification of Islamic perspective that influences Muslims' perception to fathom the Javanese notion. People hitherto tend to perceive some Javanese notions like the mythology of triangle power as discussed in the previous chapter as a kind of superstition rather than symbolic relation (as analyzed by Heddy AhimsaPutra) that used to be recognized by Javanese people and integrated in their daily life. ${ }^{25}$

Historically, Islam came and was accepted easily by Javanese people because of the openness and flexibility of Javanese culture on one hand, and because of creative and peaceful propagation as initiated by Wali Songo as the Islamic missionaries who first brought Islamic teaching to Java. Hence, both traditions then are amazingly assimilated, acculturated, and syncretic. ${ }^{26}$

I appreciate Ahimsa-Putra conceptualization that the process of acculturation between Javanese culture and Islamic culture is through symbolic relation; genealogic relation, analogical relation, historic relation, prophetic relation,

25 Y. Argo Twikromo, Mitologi Kanjeng Ratu Kidul (The Mythology of The Queen of Southern Ocean), p.13.

26 To know the early Islam in Java, see Mark. R. Woodward, Islam in Java: Normative Piety and Mysticism, p. 83-118, while about the process of acculturation and syncretization between Javanese culture and Islam, see Heddy Shri Ahimsa-Putra, Strukturalisme LéviStrauss: Mitos dan Karya Sastra, p.349-386. 
and cooperative relation.

However, he indicated that those patterns tend to decrease although do not completely vanish. Thus, he suggested to continually reinterpreting those symbolic relations in order to be more accepted in the mind of Javanese people. He offered what he named as logic-transformational relation. ${ }^{27}$ Unfortunately, he did not mention the example of the relation. In this point, I attempt to offer that kind of relation, i.e. what I call cosmological relation. It means that we can take and contextualize one of the important notions in Javanese culture i.e. the cosmological concept, to see the nature as an inseparable and integrated entity of human beings and to always sustain the balance of jagad cilik (micro cosmos) and jagad gede (macro cosmos). This is probably one way to reinterpret the Javanese notion in order to be more acceptable and more rational in the minds of people hitherto.

On the other hand, in the current decade of Indonesia, there is an indication of purification and Arabization in the sense that Islam in Indonesia is perceived as less Islamic or not authentic rather than what is perceived as original Islam. ${ }^{28}$ This movement is explicitly obvious in the way Islamic leaders encourage people to be aware of some Javanese notions and rituals in which they assume as superstition and un-Islamic, and implicitly evident that in some extents, the people perceive Javanese culture as syirk.

We can see this tendency in the case of Nurhidayati in that she commits to purify her communities' faith from what she calls a kind of syirk such as believing in the myth of Nyai Roro Kidul, attending some Javanese ritual, etc. We can also see this in the case of Rebo Bungkasan ritual in which the decreased number of visitors is related to the people's perception that the ritual is also a form of syirk.

This pattern of contestation indicates that Javanese notions and Islamic notions are in a strained relation. The process of acculturation between those two cultures that has been amalgamated for centuries, today they have come under tension.

27 Ahimsa-Putra, p. 383.

28 The purification movement was intensified since Islamic leaders adopted and claimed Arabic Islam as the purest Islamic notions. This movement met its momentum when Iran Revolution proclaimed as the initial awakening of Islamic state. It then has been affecting the plurality of acculturation between Islam and local culture such as going on in Indonesia. To see the discussion of local Islam in Indonesia and the notion of purification and Arabism, see Abdul Mun'im Dz, "Mempertahankan Keragaman Budaya" (To Sustain Plurality of Culture) in Tashwirul Afkar. No.14, 2003. 


\section{Religious Meaning Vs Scientific Meaning}

To see the contestation between religious meaning and scientific meaning, let me exemplify what Katib stated:

So, the earthquake is part of the law of cause-effect and the cause-effect law is reasonable law. It means that there is nothing in this world that cannot be searched, however, God also creates something beyond logic for example the creation of the Christ. It is the way God reminds and warns human being in order to not deify intellect. The earthquake is a warning, in which the ability of intellectuality is limited, that's why it cannot be predicted yet until today. Yet, for me, the first thing that we must stand is our faith, what scientific achievement will always support religious notion and strengthen the faith. Not inversely; not believing in religious notion after sciences strengthening what religion teachings have explained.

He was implicitly worried that science will replace the role of religion in the sense that science should not be placed in the first stage; religion is the first one to be recognized as a viewpoint. However, he assumes that science will be always in line with religion, and he also expects that what science will reach could support religious teachings.

We can see in the case of Nurhidayati and Akhid, from religious teachings they conceive that a certain occurrence like earthquake happen because of God's will. Everything is under the predestination of the Omnipotent, yet they need more explanation why it happens. In the terms of Yunus, we should not end in takdir (predestination). We need to understand and explain a takdir by scientific achievement.

From this ambiguity in fathoming religious teaching and scientific inquiry, it can be simplified that the villagers actually need more rational explanation to understand natural phenomena such as an earthquake. However, they are worried if they believe scientific explanation they will lose their religious perspective. They are in a dilemma; "which one comes first; explanation based on revelation or reason, revelation or reason that should be taken first to respond and to understand something surrounding human being".

\section{CLOSING}

Disaster study is a very broad area of study, yet in Indonesia, it is very scarce in which students and researchers who are interested in the topic especially from a social and cultural point of view. This paper is just a starting point in disaster studies that I attempt to contribute to academically. It is, of course, full 
of critical and debatable spaces that can be discussed further in a broader and in more comprehensive way.

As aforementioned discussion, the focus of this study is to scrutinize Yogyakarta people's responses to the earthquake that happened on May 27, 2006. In doing so, I trace the way they construct their responses. There are three roots behind the minds of the villagers in responding to the earthquake; religious notions, Javanese beliefs, and natural explanation. Those three streams contest each other. Nevertheless, the result of the research is that the villagers' responses are dominated by religious notions (religious meaning) rather than Javanese beliefs (Javanese meaning) and natural explanation (scientific meaning).

However, although religious meaning is dominant, it is not a single response. There are variations behind the religious response i.e. earthquake as a punishment from God, a warning from God, and a test from God. These responses are still problematic both in the light of theodicy and in the light of the recovery process that tend to blame the victims.

Finally, to sum up the discussion, I would like to propose that some propositions in this paper will be a means to shift our paradigm in order to conceptualize a more holistic and more acceptable worldview in our era of disaster prone country and environmental crisis. Indeed, it needs further discussion through more comprehensive study and more fruitful dialogue among scientists, social scientists, theologians, and local leaders.

\section{BIBLIOGRAPHY}

Abdullah, Irwan, 2006, Dialektika Nature, Kultur dan Struktur: Analisis Konteks, Proses, dan Ranah dalam Konstruksi Bencana, Yogyakarta:UGM.

Afnan, Soheil M., 1958, Avicenna: His Life and Works, London: George Allen \& Unwin Ltd.

Ahimsa-Putra, Heddy Shri, 1997, "Sungai dan Air Ciliwung: Sebuah Kajian Etnoekologi" in Prisma 1, Januari 1997.

Amhar, Fahmi, 2006, "Mitos, Sains dan Iman di Tengah Bencana" in Kedaulatan Rakyat, June 12, 2006.

Anderskov, Christina, 2004, Anthropology and Disaster, www.AnhtroBase. com

Armstrong, Karen, 2005, A Short History of Myth, New York: Canongate.

Bankoff, Greg, Georg Frerks, and Dorothea Hilhorst (Eds), 2004, Mapping Vulnerability, London: Earthscan.

Benz, Arnold, 2003, "Tragedy Versus Hope: What Future in an Open Universe?” in Willem B. Drees, Is Nature Ever Evil? Religion, Science and 
Value. New York: Routledge.

Blaikie, P., T. Cannon, I. Davis and B. Wisner. 1994. At Risk: Natural hazards, people's vulnerability, and disaster. London. Routledge.

Cahanar, P., 2005, Bencana Gempa dan Tsunami, Jakarta: Penerbit Buku Kompas

Chester, David K., 2005, Theology and Disaster Studies: the Need for Dialogue, Journal of Volcanology and Geothermal Research 146 (2005) 319-328.

Drees, Willem B, 2003, “This Vale of Tears - The Best of All Possible Worlds?" in Willem B. Drees (Ed.), Is Nature Ever Evil? Religion, Science and Value. New York: Routledge.

Fritz, Charles E., 1989, "Disasters" in David L. Sills (Ed) International Ecyclopedia of Social Sciences, Vol. 4.

García-Acosta, Virginia, 2002, "Historical Disaster Researh” in Susanna M. Hoffman and Anthony Oliver-Smith (Eds), Catastrophe \& Culture: Anthropology of Disaster, Santa Fe: School of American Research Press.

Hefner, Philip, 2003, "Nature Good and Evil: A Theological Palette", in Willem B. Drees, Is Nature Ever Evil? Religion, Science and Value. New York: Routledge.

Hoffman, Susanna M. and Anthony Oliver-Smith, 1999, The Angry Earth: Disaster in Anthropological Perspective, New York: Routledge.

Homan, Jacqueline, 2001, A Culturally Sensitive Approach to Risk? "Natural" Hazard Perception in Egypt and the UK, Australian Journal of Emergency Management, Winter-2001.

Inati, Shams C, 2000, The Problem of Evil: Ibn Sînâ’s Theodicy, New York: Global Publications.

Koentjaraningrat, 1994, Kebudayaan Jawa, Jakarta: Balai Pustaka.

Martin, Richard C., and Mark R. Woodward with Dwi S. Atmaja,1997, Defenders of Reason in Islam: Mu'tazilism from Medieval School to Modern Symbol, Oxford: One World.

McGuire, Meredith B., 1981, Religion: The Social Context, California: Wadsworth Publishing Company.

Munjid, Ahmad, "Memperebutkan Makna Bencana" in Koran Tempo, April 13, 2007.

Ngelow, Zakaria J.(Ed.), 2006, Teologi Bencana, Makassar: OASE INTIM

Novriantoni, 2005, Tuhan Pasca-Tsunami, KOMPAS (Opini), January 14, 2005

Oliver-Smith, Anthony, 1996, "Anthropological Research on Research and "Disasters" in Annual Review of Anthropology.1996.25: 303-28

Oliver-Smith, Anthony, 1996, "Disaster Studies" in David Levinson and Melvin Ember (Eds), Encyclopedia of Cultural Anthropology, New York: Henry Holt and Company. 
Ormsby, Eric L., 1984, Theodicy in Islamic Thought: the Dispute Over Al-Ghazali's "Best of All Possible Worlds", New Jersey: Princeton University Press.

Pelling, Mark, 2003, "Paradigms of Risk" in Natural Disasters and Development in a Globalizing World, New York: Routledge.

Radford, Luis, 2006, “The Anthropology of Meaning” in Springer 2006.

Schlehe, Judith, 2007 "Cultural Politics of Natural Disasters: Discourses on Volcanic Eruptions in Indonesia" in Michael J. Casimir and Ute Stahl (eds.) Culture and the Changing Environment: Uncertainty, Cognition, and Risk Management in Cross-Cultural Perpsective, New York: Berghahn.

Spradley, J.P., 1975, “Adaptive Strategies of Urban Nomads: the Ethnoscience of Tramp Culture" in J. Friedl and N.J. Chairman (eds), City Ways: A Selective Reader in urban Anthropology, New York: Thomas Y. Cromwell.

Winardi, A., at al, 2006, Gempa Jogja, Indonesia, and Dunia, Jakarta: Gramedia.

Wisner, Ben, Piers Blaikie, Terry Cannon, and Ian Davis (Eds), 1994, At Risk: Natural Hazards, People's Vulnerability and Disasters, New York: Routledge.

Woodward, Mark. R.,2001, Islam in Java: Normative Piety and Mysticism (Transl.), Yogyakarta: LKiS.

Zoetmulder, P.J., 1983, Kalangwan: A Survey of Old Javanese Literature, Jakarta: Djambatan. 